\title{
Comparison of Development of Non-governmental Organizations and the Current State of Their Funding in Slovakia and Austria ${ }^{1}$
}

\author{
Mária Svidroňová ${ }^{2}$, Gabriela Vaceková ${ }^{3}$
}

\begin{abstract}
Non-governmental organizations play a vital role in the economy of every country. They are not only providers of special type of services that public sector is not capable of providing in full quality and quantity, and private sector is not interested in, but they are also watch dogs of the society and builders of active citizenship. Thus they have become an object of many research studies. The divergence in their goals, sizes, roles, types of services provided, and ways of funding make NGOs an interesting subject. As a goal for our research we therefore chose a comparison of the development and state of the Slovak and Austrian non-profit sector in the view of historical development of both countries. Consequently, we want to evaluate the funding of NGOs in Slovakia and Austria. In the paper we map the development of non-profit sector in Slovakia and Austria and in the context of a common historical development we assess a current state and a potential of economic strength of NGOs in both countries. The output is comparison of funding of NGOs in Slovakia and Austria based on statistical data evaluation. Subsequently, we propose recommendation for suitable diversification of the funding sources.
\end{abstract}

Keywords: non-profit, non-governmental organizations, funding, Slovakia, Austria

JEL Classification: L30, L31, L39

\section{Introduction}

A scientific research of John Hopkins of University in Baltimore (USA) was the impulse for us to write the paper we are presenting here. The output of Hopkins' work consisted of studies internationally comparing non-profit sector, describing the size and power of diverse indicators. The research took part in the 1995, twenty-two countries participated, among them Slovakia and Austria.

\footnotetext{
1 This work was supported by the project „Employment of Newly Graduated Doctors of Science for Scientific Excellence“ (CZ.1.07/2.3.00/30.0009) co-financed from European Social Fund and the state budget of the Czech Republic.

${ }^{2}$ Ing. Mária SVIDROŇOVÁ, PhD. Univerzita Mateja Bela v Banskej Bystrici, Ekonomická fakulta, Katedra verejnej ekonomiky a regionálneho rozvoja, Tajovského 10, 97401 Banská Bystrica, SR, e-mail: maria.svidronova@umb.sk.

${ }^{3}$ Ing. Gabriela VACEKOVÁ, PhD. Masarykova Univerzita, Ekonomicko-správní fakulta, Katedra veřejné ekonomie, Lipová 41a, 60500 Brno, gabriela.vacekova@econ.muni.cz.
} 
These countries were part of the Austro-Hungarian Empire from 1867to 1918. Nonprofit sector existed even in this period, and was represented by charity and various voluntary associations and self-help groups or institutions providing social and health services for the poor. After the collapse of the monarchy, the non-profit sector developed in successors of the Empire, in Czechoslovakia and Austria. Different political regimes and economic conditions affected the non-profit sector and its formation in both countries.

Austrian non-profit sector and its development is described in detail in numerous research studies that were written mainly at Vienna University of Business (Haider et al. 2008, Schneider et al. 2007; Trukeschitz 2006; Badelt 2002; Heitzmann 2001; Bachstein 2000; Bachstein 1997; Badelt - Bachstein et al. 1997). Also, for Slovakia, the development of non-profit sector and its organizations was analyzed and described in several studies and publications (Kuvíková, 2004; Marček, 2004, 2010; MarkowskaBzducha, 2010; Nemec - Meričková - Štrangfeldová, 2010; Nemec - Orviská - Pisár, 2010; Ondrušek, 1998; Stejskal et. al., 2012). Thus we do not want to devote this paper to analysing the historical development as such, we focus on selected issues only. As for political development, we describe several regimes and their influence on the number of non-government organizations in both countries. Another point of view is presented by economic development, where we provide characteristics of the share of nongovernment organizations on GDP in both countries.

Despite population of the two countries is comparable and they share political and cultural past, the number of diverse economic and non-economic factors seems to have led - among others - to different evolution of NGOs, of their environment and their funding strategies. Austrian NGOs have a very strong state support and their use of public funding is very significant. On the other hand, since the very beginning of political and economic transformation of Slovak society after 1989, Slovak NGOs have often received external non-state funding as a consequence of massive resource distribution from U.S. and then EU-based development agencies and foundations that aimed to build the infrastructure of Slovak civil society and its advocacy capacities. This fact combined with a relatively low political and material support from the state (most notably during the first decade of Slovak political and economic transformation) made many NGOs search for non-public financial sources and focus more on self-financing activities. A different historical experience of civil society or citizens with the state power might be another important factor influencing the relations between civil society actors and the state: While Slovakian discourse on civil society that prevailed after 1989 and was launched by dissidents after 1968 clearly perceived the civil society and the state as two separate and even inimical entities, Austrian experience of corporate-like patterns in political and social setting led to somewhat different relations of NGOs and the state. This may have led to somewhat cautious relations between Slovak political elites and NGOs, and to subsequent relatively lower extent of funding from public sources in the Slovak Republic compared to Austria. Therefore, the effects of varying extent of government support on NGO funding and on their self-financing should be considered.

According to information available, a similar study comparing development of NGOs and current state of their funding through primary research in these countries has not 
been published yet. All studies published so far have adopted a summarizing and descriptive approach.

Before the current state of NGOs and their funding in both countries is analyzed, it is important to define what the term "non-governmental organization" means. The scope of non-governmental organizations (NGOs) is so diverse that it is impossible to find a single term to define them. Therefore, many authors (Anheier and Salomon, 1999; Bútora, 2011, Frič, Goulli, 2001, Haken, 2005, Hansmann, 1996; Hyánek, 2012; Kuvíková, 2004; Marček, 2004; Ondrušek, 1998; Pestoff, 2006; Petijová - Woleková, 2006; Rektořík, 2001, Rose-Ackerman, 1996; Toepler, 2003, Weisbrod, 1988) in a number of publications prefer a broader description of the characteristics of non-profit organizations. The structural-operational definition by Anheier and Salamon (1998) can be used. According to this definition, an NGO should meet five characteristics: institutionalization, independence, non-profit, self-government, and voluntary participation.

\section{Goal, Data and Methodology of Research}

The goal of the paper is to compare development and state of the Slovak and Austrian non-profit sector in view of historical development of both countries, and consequently to evaluate funding of NGOs in Slovakia and Austria. The countries were chosen for several reasons, e.g. availability of comparable outcome, joint history in the Habsburg monarchy, and interesting findings for neighbouring countries.

Non-profit organizations can be classified according to their founders or proprietors as governmental (non-profit state) and non-governmental (non-profit private) organizations. We focus on non-governmental organizations that comply with Salamon and Anheier characteristics of NGOs mentioned above. In Slovakia, such NGOs are represented by four main types of organizational-legal forms:

- Civic associations

- Foundations

- Non-investment funds

- Public benefit organizations

Criteria for selection of respondents were as follows: NGO is registered (a) at the Ministry of Interior (obligatory criteria to meet the aforementioned definition of institutionalization), and (b) NGO is active. Activity was measured by two criteria: whether NGO was registered for tax assignation in previous year and whether it has a functional webpage. It is assumed active if an organization makes efforts to register at the notary for tax assignation (it costs about 50€) and promotes its activities to receive the tax assignation. To confirm activeness, we visited the website and checked for its functionality and up-to-date content. Only these organizations were included in the research file which consisted of 10,014 organizations of all four main types in 2011. We obtained it with quota sampling that corresponded with the original file (quotas for individual characters, e.g. quota for each type of organizational-legal form). Of the 670 surveyed NGOs we obtained data from 182 respondents in the following structure (Table 1): 
Table 1 Sample size

\begin{tabular}{lrr}
\hline Legal form & Absolute & $\%$ \\
\hline Civic associations & 152 & 83.52 \\
Foundations & 6 & 3.30 \\
Non-investment funds & 3 & 1.65 \\
Public benefit organizations & 17 & 9.34 \\
Others & 4 & 2.20 \\
Total & 182 & 100.00 \\
\hline
\end{tabular}

Source: Own research, 2011.

Chi-square test confirmed at the level of $\alpha=0.05$ that the sample is representative (pvalue is 0.129 ), which allows us to generalize the outcome of primary research for whole Slovakia.

The following legal forms of non-profit organizations are in Austria:

- "Verein" (association) - the dominant legal form (Schneider et al, 2007)

- "Stiftung" (foundation)

- "gemeinnützige Kapitalgesellschaft" (public benefit organization)

- "Genossenschaft" (cooperative).

Output of "Different sources of funding of non-profit organizations" (Schober et al., 2010) project, conducted by Research Centre NPO-Kompetenzzentrum WU Wien, constitute the source data for Austria. In their primary research conducted in 2010, they asked 266 Austrian NGOs and collected answers from 116 respondents. For Slovakia, the data are the outputs of a primary research conducted in the dissertation "Selffinancing strategy and sustainability of non-profit organization". The primary data for Slovakia was obtained by a sociological method of a structured questionnaire sent to 670 NGOs. The questionnaire for Slovak research was based on the methodology of USAID and methodology of research by Schober (2010). In order to gain as many responds as possible and to make the research outcomes valid, the questionnaire was consulted with a sociologist and with experts in the field of statistics.

The outcomes of the aforementioned research projects are comparable since similar methodology in both countries was used (Benčo-Vaceková, 2012):

- Selection of relevant NGOs in the database or on the Internet.

- Establishing a personal contact with selected NGOs at the management level.

- Sending an e-mail with a link to an online-questionnaire to contacts that have been identified in the previous step.

- Sending a reminder after two weeks after the questioning commenced.

Based on the comparable outcome of secondary data for Austria and primary data for Slovakia we can focus on comparing different funding sources that are used in these countries, their volume and characteristics. Given the limited scope of the paper, we abstract from issues of "Agency Costs" versus diversification of funding sources. 


\section{Non-profit Sector in Slovakia and Austria}

Civic and volunteer activities have had a long tradition in Slovakia. Establishment of the first non-profit organizations in this area is related to formation and activities of the church. The oldest examples are charities, institutions providing social and health services for the poor, and various brotherhoods of religious communities (Kuvíková in Zimmer, 2004).

At the turn of 19th and 20th centuries, many voluntary associations and groups with self-help mission existed in Slovakia. The first break in development of voluntarism occurred in the post-revolutionary years 1848-1849 when most of the associations ceased to exist.

Many regimes changed in Slovakia and Central Europe in the 20th century (Spaček, 2009). Slovakia was in different regimes: Austro-Hungarian Empire, Czechoslovak First Republic, Slovak Fascist State, Czechoslovak Republic 1945-48, Communist Czechoslovakia, Czechoslovakia after Soviet and Warsaw Pact Occupation in 1968, Federal Socialist Czechoslovakia, Federal Democratic Czechoslovakia, and currently the Slovak Republic formed in 1993. Despite these facts, NGOs and civil society were formed in Slovakia. There have been eight currency reform and nine constitutions in Slovakia, the country has had experience with political systems as parliamentary democracy, a fascist regime, Stalinism, 'normalization,' socialism and the postcommunist return to democracy (Hochel, 1996).

November 1989 brought political and economic changes and increased civic activities and entry of private institutions including non-profit organizations in the economy. Number of private non-profit (non-governmental) organizations and volunteers soared. By 1993, there were almost 6,000 registered non-governmental organizations. The number increased to 9,800 in one year, and by the year 1996, it was already more than 12,000 NGOs. The positive growth was complicated by the government's new restrictive laws. Administrative guidelines and limits for the establishment and funding made it difficult for the existence of the non-profit sector. In 1997 the Act on Foundations was adopted which greatly limited the independence of civic activities and as a result 1800 Slovak foundations were ceased. After the 1998 elections, a new coalition established a liberalization of regulations regarding the non-profit sector, creating favourable legal and economic conditions for its further development and existence (Kuvíková-Svidroňová, 2010).

The government that arose from the 2010 election chose the topic of civil society as important and created a representative office for development of civil society in Slovakia. Based on recommendations from this office, the Government Council for NGOs, which operated in Slovakia since 1999, was transformed to the Committee for NGOs. Resolutions of the Committee shall be automatically placed as notes to relevant materials discussed at parliamentary session (Radvanský et al, 2010). The government, however, ended early due to the election in 2012 and the present government came up with a proposal to create an office of a government representative for national minorities and civil society. Non-profit sector did not agree with this proposal, they opted for maintaining the office of an independent representative for civil society. This issue has not been solved yet. 
We can certainly say that the non-profit sector in Slovakia has a strong representation and its size is documented in Table 2.

Table 2 Development of Private Non-profit Organizations and Other Legal Entities in Slovakia

\begin{tabular}{|c|c|c|c|c|c|c|}
\hline \multirow{2}{*}{ Legal form } & \multicolumn{2}{|c|}{1998} & \multicolumn{2}{|c|}{2008} & \multicolumn{2}{|c|}{2012} \\
\hline & absolute & relative & absolute & relative & absolute & relative \\
\hline Legal entities & 83,476 & $100.0 \%$ & 169,960 & $100.0 \%$ & 222,929 & $100.0 \%$ \\
\hline of which non-profit organizations & 23,142 & $27.72 \%$ & 50,027 & $29.43 \%$ & 58,158 & $26.09 \%$ \\
\hline Of which budgetary organizations & 5,005 & $21.63 \%$ & 6,592 & $13.18 \%$ & 6,601 & $11.35 \%$ \\
\hline Of which subsidiary organizations & 988 & $4.27 \%$ & 751 & $1.51 \%$ & 681 & $1.17 \%$ \\
\hline Of which non-governmental organizations & 17,149 & $74.10 \%$ & 42,684 & $85.32 \%$ & 50,876 & $87.48 \%$ \\
\hline Of which civic associations & 12,000 & $51.85 \%$ & 25,613 & $51.20 \%$ & 28,205 & $55.44 \%$ \\
\hline Of which foundations & 422 & $1.82 \%$ & 394 & $0.79 \%$ & 416 & $0.82 \%$ \\
\hline Of which public benefit organizations & 16 & $0.07 \%$ & 2,006 & $4.01 \%$ & 2,111 & $4.15 \%$ \\
\hline Of which non-investment funds & 161 & $0.70 \%$ & 625 & $1.25 \%$ & 483 & $0.95 \%$ \\
\hline Of which other & 4,550 & $19.66 \%$ & 14,046 & $28.08 \%$ & 14,265 & $28.04 \%$ \\
\hline
\end{tabular}

Source: Statistical Office of the Slovak republic, 2013.

Table 2 shows the number of all legal entities including corporations (profitable institutions) and government organizations, so we can see the share of non-profit sector on the total number of legal entities (e.g. out of non-profit organizations the non-governmental organizations have a share of $74 \%$, non-profit sector creates $27 \%$ of all legal entities in Slovak economy). From Table 1, it is also clear that the non-profit sector has increased in the past 20 years. Less than ten years after the revolution, there were 23.142 nonprofit organizations in Slovakia, from which 17,149 were non-governmental. This number has more than doubled in the following ten years (year 2008 in Table 1). The most up-to date data are available for year 2012, and only prove the increase in the number of non-profit organizations although some legal forms have decreased (non-investment funds).

Growth in the non-profit sector in Slovakia can be also monitored through employment in this sector. According to the Statistical Office 20.938 employees worked in NGOs in 2010 and further 269.714 volunteers participated, which when converted to full-time employment, gives additional 7.178 workers. For different part-time contracts, 63.618 employees worked in non-profit sector. We do not have data separately for NGOs (for further characteristics of importance of NGOs in Slovakia see e.g. Kuvíková - Raguseo, 2008).

The non-profit sector has a long tradition in Austria, and many of the NGOs that are active today have a history that goes back to the 19th century. Law on registered associations, which was established in 1867, was the foundation for the formation of the civil 
society sector. Charitable societies and saving clubs, which reflected the lack of a public system of social security and the necessity for the working class to save for unpredictable event, were most important types of associations, from around the turn of the century until 1914. Also, the political parties of the Austrian Republic have roots in registered associations active in these times. During World War I, activity of the nonprofit sector supposedly diminished. However, the sector recovered and grew very quickly afterwards. In the Interwar Years - when fascist ideology gained ground in Austria - civil society associations played an important role in disseminating fascist thoughts, which manifested themselves within such associations first, especially sports associations. Thus, associations served to disguise political activity and contributed to keep fascist ideology publicly unnoticed before emerging across the board (Simsa et al., 2006).

Steady increase in the number of NGOs that occurred from 1925 came to a sudden end in 1934 when the Social Democratic Party and all associations linked with it were dissolved, and any further activities forbidden. Associations with 'undesired' aims were either shut down or brought in line with nationalistic goals. All Jewish associations were dissolved. Membership in those NGOs which were co-opted by the regime was partly obligatory (Heitzmann - Simsa, 2004). After World War II and with the formation of the Second Republic, restoration of the non-profit sector was influenced a lot by political parties. Many NGOs were founded or supported either by the Social Democratic Party or by the conservative Austrian People's Party (ÖVP). Following the retreat of the Church from current political affairs, some of the NGOs associated with the Church started to work closely with the ÖVP (Simsa et al., 2006). Due to these affiliations, NGOs had an enormous influence on politics. This constituted the base for the corporatist system Austria has today, within which not only political parties but the labour movement, too, professional associations, and NGOs in general are represented.

In 1973, many ecological, cultural and political movements that had been developing throughout the 1960s resulted in founding of a huge number of registered associations. Charity associations engaging in activities for disadvantaged people (like drug addicts) and a number of self-help groups and organizations delivering services emerged. The number of registered associations in Austria has been increasing steadily since then. One of the more recent occasions that motivated action within the civil society sector came about in 2000, when in the course of protests against new right-wing government, a great number of initiatives emerged spontaneously (Schneider et al, 2007).

Although non-profit organizations play a significant role in Austrian society, there scarce statistical records which might provide official data on their quantitative development. Many non-profit organizations are not subject to any reporting requirements (Schneider - Haider 2009). Moreover, heterogeneity of NPOs complicates capturing the NPOs, both based on their legal form as well as on their field of activity. Most Austrian NPOs meet the non-profit criterion, but they are not recorded centrally. Different studies (see e.g. Rameder - More-Hollerweger 2009; Neumayr et al 2009; Neumayr - Schober 2008; Millner et al 2008) and statistics (see e.g. Statistics Austria) thus help complete the puzzle by NPO to complement sector, but a regular, systematic coverage of the sector within the framework of the national accounts cannot be ultimately replaced (Meyer et al. 2010). These studies were conducted in the past 
decades with the aim to map the Third Sector in terms of employment, volunteering and the identification of sources of funding, major functions (e.g. service delivery and advocacy) etc. But due to the lack of a comprehensive official NGO-register and therefore a lack of information on the basic population of NGOs the picture of the Third Sector has always been a mosaic of various empirical data mostly driven by research institutions rather than by the public office of statistics, though sometimes in collaboration with the latter.

As we can see, non-profit sector in both countries has its ups and downs. Whilst in Austria, NGOs started to develop (and in co-operation with political parties) as early as in the 1960s, in Slovakia the communism era delayed the restoration and slowed down the development of NGO until 1989.

\section{Research Sample of NGOs in Slovakia and Austria}

Most of the NGOs surveyed are active in the field of sport $(21.43 \%)$, culture $(19.23 \%)$ and education (18.13\%). Almost $20 \%$ of them (19,78\%) reported as their core work "other" and indicated options as environment, development and humanitarian aid, social and legal protection, defence of citizens' rights and interest activities, spiritual development, youth work and organization of cultural events and managing the leisure time. Figure 1 summarizes the overview:

Figure 1 The Core Work of Slovak NGOs

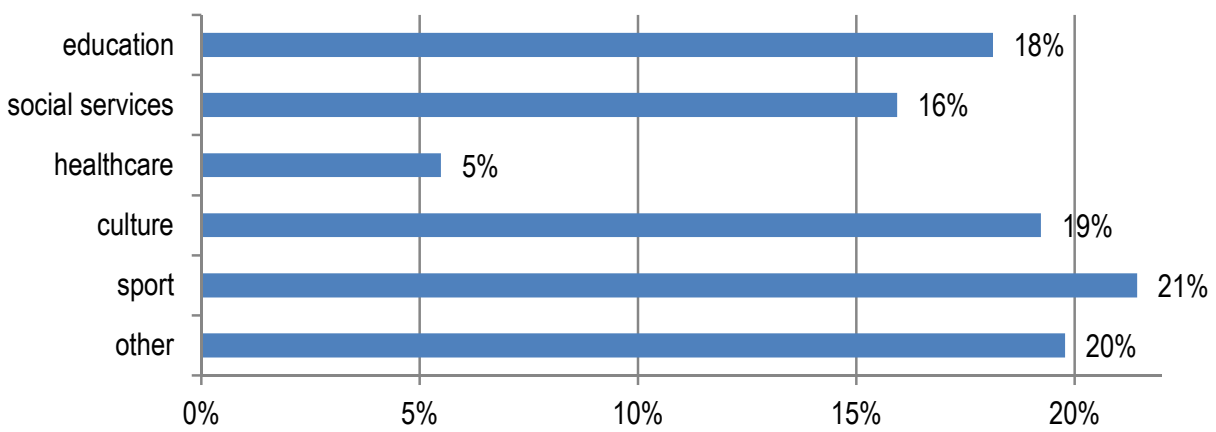

Source: Own research, 2011.

As far as number of staff (both paid employees and unpaid volunteers) is concerned, we can say that half of the NGO personnel are volunteers. Full-time employees are represented by $19 \%$ and part-time employees are represented by $19 \%$. External co-workers, mentors, tutors and occasional co-workers were marked as "other" (Figure 2). 
Figure 2 Staff Composition of Slovakian NGOs

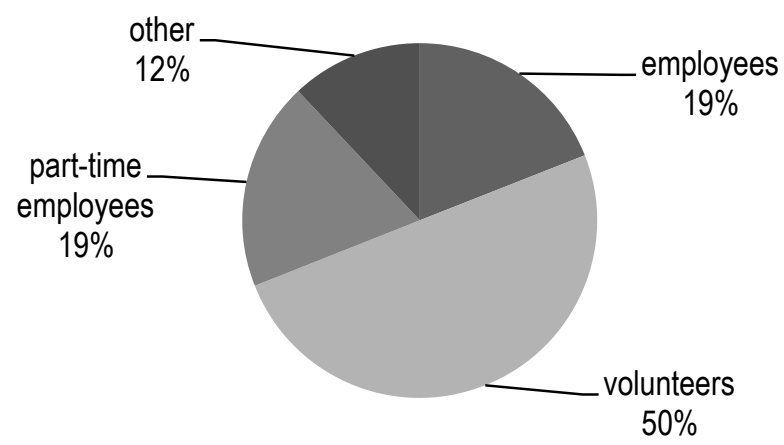

Source: Own research, 2011

The data available obtained by nationwide poll of NGOs in Austria in 2010 shows that the number of employees in this sector is about 170.113. Approximately 59\% of the employees work in the field of social and health services. Further $55.67 \%$ of staff is employed only part-time (Haider et al, 2010).

These figures only illustrate the non-profit sector in Austria; In order to describe the size of its real economic power, it would be necessary to research more complex macroeconomic indicators, which is not the goal of presented article.

Data describing the financial situation of NGOs in Austria come from the project conducted by the research institute for non-profit sector - WU Wien (NPO-Institute) entitled "Financing of NGOs." The project deals with an extensive primary research on various sources of funding of non-profit organizations (Schoeber et al., 2010).

In 2010, there were 266 respondents from Austrian NGOs that were selected from the database of NPO Institute, containing ca. 4,000 NGOs. A questionnaire was completed by 116 NGOs, which corresponds to return at 43.6\%. In Austria, NGOs data have to be collected from various sources since NGOs are not officially registered as such, and there is only a very limited access to the register of associations (Zentraler Vereinsregister), the most common legal entity of NGOs. In terms of absence of official data on NPOs in Austria, it is not possible to achieve absolute representativeness of the research sample. A significant proportion of participating NGOs (28\%) comes from Vienna and is active in the social field (social services), which is typical for the Austrian non-profit sector. 
Figure 3 The Core Work of Austrian NGOs by ICNPO

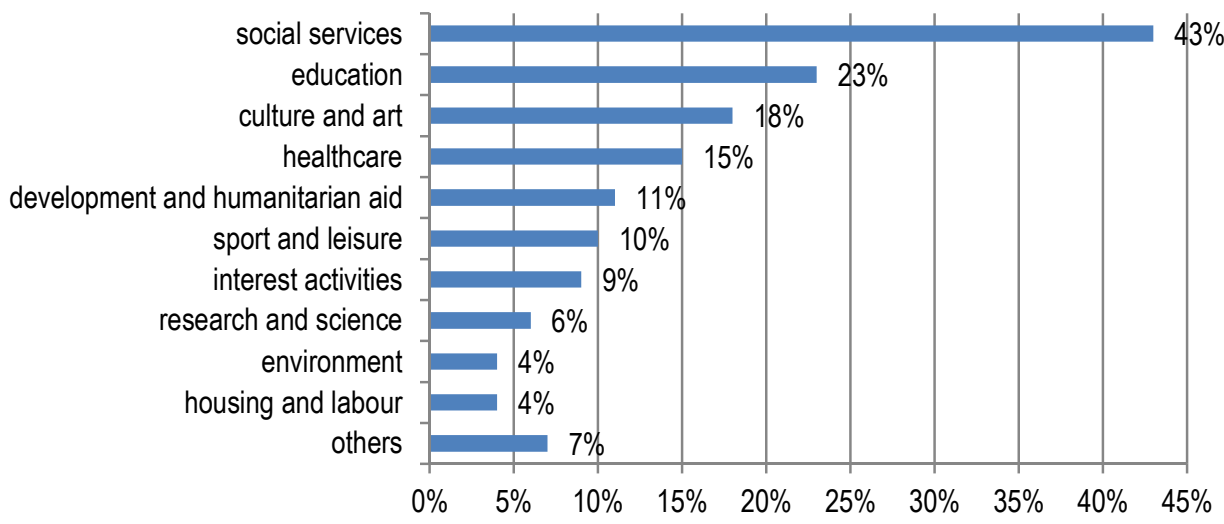

Source: Schober et al, 2010.

Compared to data on revenue and employment (e.g. Heitzmann 2001, Schneider Haider, 2006), ICNPO classified NGOs are highly represented in social services (43\%), education (23\%) and culture and art (18\%). We can say that education, social services, culture and sport are significant sectors for NGOs activities in both countries.

Number of employees is yet another feature that can be compared between Slovakian and Austrian NGOs. According to median, 21 paid employees and 5 unpaid voluntary co-workers work in a single NGO. From this point of view we can say that Austrian NGOs are more professional: they have $45 \%$ of employees (Figure 4) compared to Slovak NGO with $19 \%$ of employees (Figure 2). On the other hand, Austrian NGOs do not use labour of volunteers as much as Slovak NGOs as it is recommended by Rehli and Jäger, (2011), especially for international NGOs.

Figure 4 Staff Composition of Austrian NGO

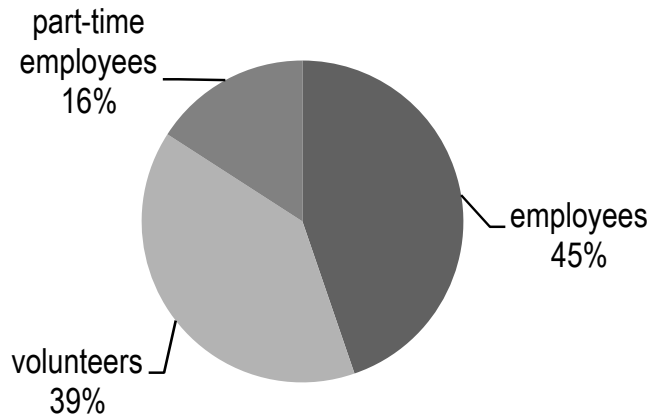

Source: Schober et al, 2010. 
Based on the definition of the characteristics of the environment in both countries in which the research was conducted, we can proceed to analysing of the funding of NGOs in Slovakia and Austria.

\section{Funding of NGOs in Slovakia and Austria}

There are several approaches how to define funding for NGOs (e.g. Weisbrod, 1998; Salamon - Anheier, 1998; various studies published by John Hopkins University). We chose an innovative approach by Schober (2010) who names the main types of funding in a similar way to business sphere. We prefer this approach as it becomes a trend in the non-profit sector to professionalize in the finance management. The main division of sources of funding NGOs follows the microeconomic division on equity and borrowed capital. The concept of equity is problematic in many NGOs as they do not have any equity in the business or economic meaning. Generally, there is a lack of investors who would provide capital in anticipation of earnings. Classic features of equity are often undertaken by donors, providers of subsidies or members of the organization. To take into account this aspect we use the term "quasi-equity" (Schober et al., 2010).

The "quasi-equity" can be divided into typical non-profit incomes and standard commercial incomes. Incomes primarily related to the main core work and mission of an NGO are understood to be typical non-profit; these incomes may come from a variety of funders.

Commercial incomes are, on the contrary, incomes from activities non-related to the mission of an NGO. In particular it is income from investment activity or yield of capital (e.g. income from renting its assets). Commercial income also applies to restructuring of assets and includes sale of assets and the associated effects of financing, such as the sale of buildings and real estates. Other commercial income is a residual category that includes all the commercial activities carried out by NGOs that are not related to their mission, and cannot be assigned to any of the other commercial income categories at the same time.

The borrowed capital can be divided into common bank loans and other subsidized borrowed capital, i.e. loans that are provided by government authorities and designed specifically for NGOs. Government supports NGOs and thus provides this capital also by assumption of guarantees or remission of debts and taxes (Svidroňová - Vaceková, 2013).

Results of our research showed that almost $88 \%$ of Slovak NGOs use multiple sources for their funding. Any NGO risks a lot if it depends on one financial source only, for the source may fail. However, $12.09 \%$ of NGOs currently relies on only one source of funding. Representation of funding sources is shown in Figure 5: 


\section{Figure 5 Sources of Funding of Slovak NGOs}

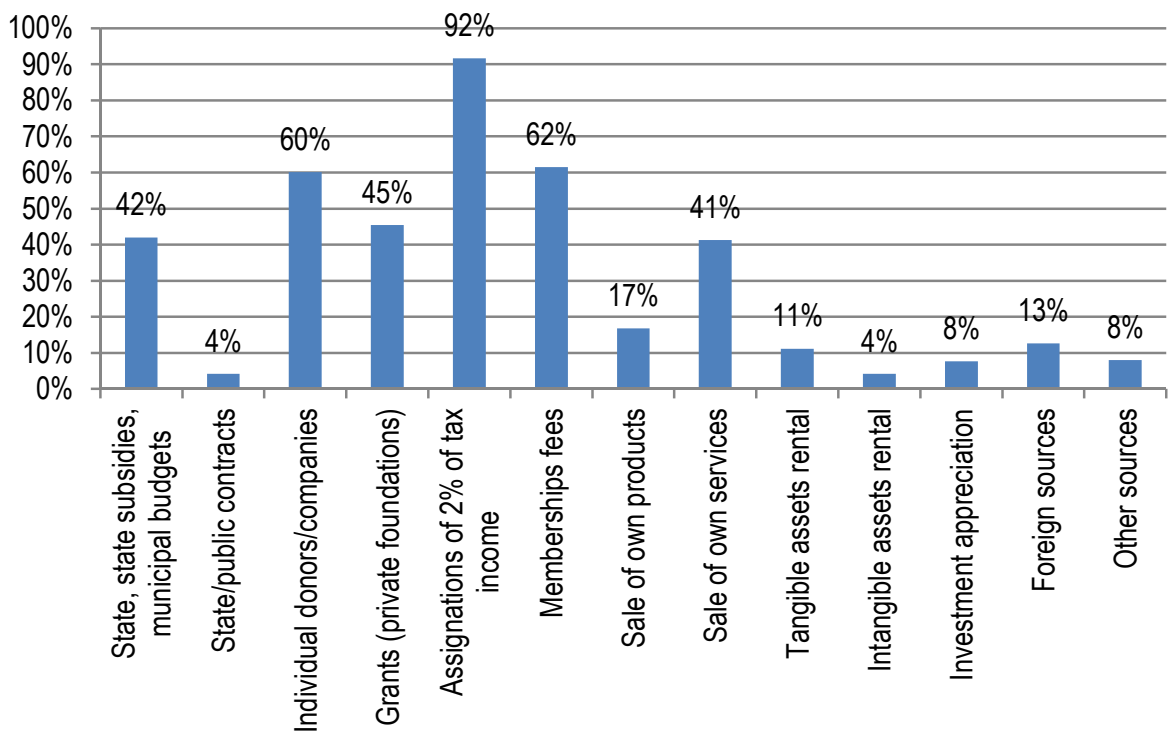

Source: Own research, 2011.

$12.64 \%$ of organizations selected "Other sources" as sources of funding. They either have not specified the other sources, or indicated a method of financing such fees for services or gift items. These forms of funding are understood as self-financing, which we examine separately. If we separate those who said self-financing activities for the option of "other", we gain new information of $8 \%$ of NGOs that use other sources of funding but do not specify them further. The structure of funding is dominated by private and individual sources also significant is self-financing and public funding. The ratio of internal and external sources is 1:3 and foreign to domestic is 1:24.

The current funding sources in Austrian NGOs correspond to the presumed structure, i.e. public finance is obviously the source that is used most frequently. Even $91 \%$ of the research participants receive funds from state grants and subsidy contracts. Fees for services and products, donations from individuals, sponsorship and membership fees (Figure 6) are other frequently used funding sources. 
Figure 6 Sources of Funding of Austrian NGOs

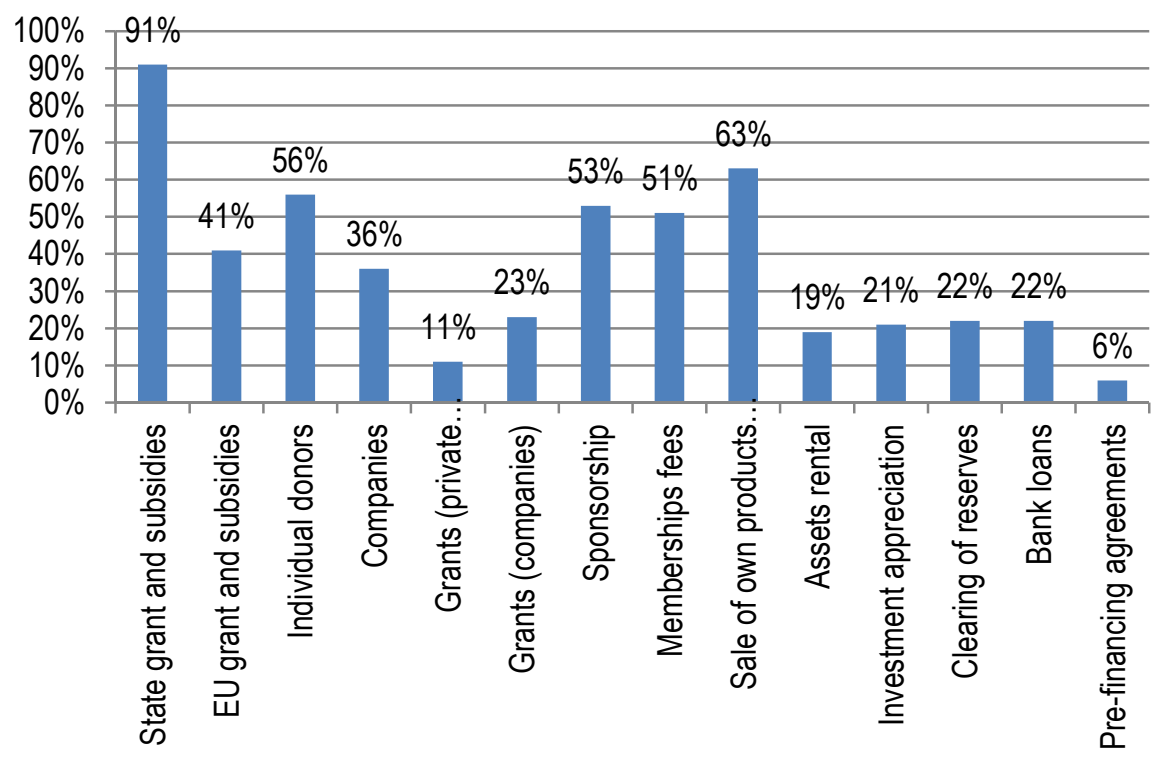

Source: Schober et al, 2010.

Outcomes of the Austrian research showed that the structure of funding of NGOs is characterized by a high concentration of funding in relatively few types of sources. Highly represented sources are funds from the state (public sources) that contribute with the largest part to the funding of most Austrian NGOs. Income from investments in comparison to the amount of funds is not significant. The outcomes of research also show that in the future, NGOs in Austria want to raise funds mainly through donations and sponsorships (Schober, 2010). In Slovakia, the situation is quite different. Slovak NGOs cannot rely on support from state grants or public sources. Income tax amounting to $2 \%$ is the most significant source of funding in Slovakia, which is logical as we used this criterion to select research sample. Highly represented are fundings from private sources and non-commercial self-financing activities. In terms of quasi-equity and borrowed capital, non-profit income as a part of quasi equity prevails in both countries.

Funding and other characteristics under observation are summarized in Table 3 (reflecting the outcomes from scientific research of John Hopkins University in Baltimore and insufficient statistical data for Austria which had to be completed by secondary data based on Schober, 2010). 
Table 3 Comparison of Selected Characteristics

\begin{tabular}{lrrrr} 
& $\begin{array}{c}\text { Slovakia 1995- } \\
\text { 1998 }\end{array}$ & $\begin{array}{c}\text { Slovakia } \\
\text { 2011 }\end{array}$ & $\begin{array}{c}\text { Austria } \\
\text { 1995 - 1998 }\end{array}$ & $\begin{array}{r}\text { Austria } \\
\mathbf{2 0 0 8 ~ - 2 0 1 1}\end{array}$ \\
\hline Population (in mil.) & 5.3 & 5.4 & 7.9 & 8.5 \\
GDP (in mil. EUR) & 19,319 & 69058.2 & 191190.0 & 300712.4 \\
Number of NGOs & 17,149 & 42,122 & n.a. & 109,346 \\
Field of core work (main 3 sectors) & n.a. & $\begin{array}{r}\text { sport, culture, } \\
\text { education }\end{array}$ & n.a. & $\begin{array}{r}\text { social services, } \\
\text { education, culture }\end{array}$ \\
Share of NGOs on employment & $0.9 \%$ & $1.3 \%$ & $4.5 \%$ & n.a. \\
Share of NGOs on GDP & $1.4 \%$ & $1.2 \%$ & $3.0 \%$ & n.a. \\
Value added as \% of GDP & $0.5 \%$ & $0.89 \%$ & $2.5 \%$ & n.a. \\
Revenues from Public sector & $22.1 \%$ & $22.8 \%$ & $47.3 \%$ & $66 \%$ \\
Revenues from Private giving & $23.7 \%$ & $68.0 \%$ & $5.7 \%$ & $31.5 \%$ \\
Revenues from Self-financing & $54.2 \%$ & $23.1 \%$ & $47.0 \%$ & $29.14 \%$ \\
Volunteers (FTE in thousands) & 7 & 7.9 & 41 & 3,019 \\
Share of employees within an NGO & n.a. & $19.0 \%$ & n.a. & $45.0 \%$ \\
Share of volunteers within an NGO & n.a. & $50.0 \%$ & n.a. & $39.0 \%$ \\
\hline
\end{tabular}

Source: Own elaboration using data of Statistical Office of the Slovak republic and data of Statistical Office of Austria, 2011 completed by secondary data based on Schober, 2010

We conclude that despite the countries can be compared as far as size is concerned, share past in the Austro-Hungarian monarchy, the influence of economic and noneconomic factors leads to different development of NGOs and their funding. We chose 3 comparable sources from different types of funding: public, private and self-financing. Austrian NGOs have very strong state support and taking advantage of public funding is very significant, but less than half of Slovak NGOs use this source compared to Austria. They have to search for other sources and rate of private funding represented by grants is therefore higher than in Austria, just as is financing by membership fees (funding by self-financing).

This may be given historically: As has been stated, Slovakia has been through many regimes, and all organizations that were not helpful to "building socialism" were dissolved in the era of communism and the right to associate was banned. This reflected in the fact that currently, the number of NGOs in Slovakia is lower than that in Austria, where restoration of the non-profit sector had actually started 20 years earlier, and in cooperation with political parties. Instability of political situation and severe conditions of communism made the development of non-profit sector harder and NGOs still have to earn trust of governments. This may lead to lower funding from public sources in Slovakia. Effects on funding with a bigger government support and the impact on business philanthropy stemming from it can be seen as further factors as described by Sokolowski (2012). Slovak NGOs thus rely more on individual and corporate donors (for strategies how to be successful with donors see e.g. Ko et al, 2011) and also use grants from private foundations. 


\section{Discussion}

Public sources are the most frequently used source of funding in Austrian NGOs. It is used by $91 \%$ of respondents participating in the research (Schober et al., 2010). This involves long-term contractual relationships which greatly influence the acquisition of new sources of funding. The question how much effort NGOs have to put in to keep these sources whilst obtaining new financial sources and fulfilling their missions comes to the fore. The need to fulfil the mission and achieve the generally beneficial goals of NGOs must be a priority when doing any activity bringing money in for running NGOs.

A partial aspect of this issue also includes a fixed purpose of sources and the accountability of the source provider. Compared to other sources of funding, it can be stated that the highest effort must be made by NGOs when applying for EU funds, state funds and contributions and donations from companies and individuals. This explains the research results which showed a clear desire of NGOs to gain a larger part of the funds through their own activities (Schober et al., 2010). It also confirms the importance of selffinancing as it can offer the highest level of independence and freedom in the decisionmaking process.

Similar results were obtained in research about the funding of NGOs in SVK (Svidroňová, 2012). However, there is an important difference - unlike Austria, state/public contracts (only 4\%) are the least used sources by NGOs in SVK. This suggests that suitable conditions to provide public services by NGOs in SVK are still missing. On the other hand, self-financing in SVK is represented by 25.4\% (Svidroňová, 2012), which is higher than the estimation reported in "ideal" diversification of funding sources, where respondents in a research in 2009 (Vaceková) stated that $32.14 \%$ should be state sources, $26.31 \%$ should be private sources, $21 ., 07 \%$ self-financing, $17.96 \%$ foreign sources and $2.52 \%$ other sources. Although the level of this type of financing is a quarter of the total sources of an NGO, the value of $25.4 \%$ is still lower than the European average of $36.9 \%$ (OECD, 2001).

It is important to conduct a scientific research in the field of optimal diversification of funding sources in both countries. The research could answer questions about importance of diversification in increasing the efficiency of the NGOs and costs of diversification given its contribution and also questions about development of optimization models for the efficient distribution of sources or as Klas (2010) says a question of innovative development. Thanks to an anonymous reviewer we have also other inputs for further research, e.g. to analyse not only the use of diverse funding in NGOS, but also importance of particular ways of funding within an NGO or to analyse further factors that influence funding of NGO (legal form and its influence on the funding structure).

\section{Conclusion}

In the paper we mapped development of non-profit sector in Slovakia and Austria. In the context of common historical development we tried to assess the current state and the potential of economic strength of NGOs in both countries. The output is a comparison of funding of NGOs in Slovakia and Austria based on statistical data evaluation. Subsequently, we proposed recommendation for the suitable diversification of the fund- 
ing sources, thus fulfilling the scientific goal of the paper: We made a comparison of development and the state of Slovakian and Austrian non-profit sector in view of the historical development of both countries, and consequently we managed to evaluate the funding of NGOs in Slovakia and Austria.

Unlike enterprises in the profit sector, whose main objective is to maximize profit, nongovernment organizations fulfil the public benefit, which is the purpose for which they were established (Brinckerhoff, 2011). It follows different financial policies of these organizations which focus primarily on the securing liquidity (Littich, 2007). The paper mapped all basic ways of securing funds from public funding, private funding and selffinancing, and presented a comparison of Slovakian and Austrian NGOs development and the current state of their funding. We also indicated the impact of economic and non-economic factors (e.g. historical development) on the composition of the funds and suggested their further research.

We conclude by saying that despite the countries are comparable as far as size is concerned and share past in the Austro-Hungarian monarchy, the influence of economic and non-economic factors has lead to different development of NGOs and their funding. Given the limited scope of the article we abstracted from the relation of "Agency Costs" and diversification of funding sources, we mainly focused on the statistical evaluation of the collected data and their comparison. This is an initial basis for further research of the authors.

\section{Acknowledgments}

The authors are grateful to two anonymous reviewers for their very helpful comments.

\section{References}

BACHSTEIN, W. 2000. Der Nonprofitsektor im Bereich sozialer Dienste: Ergebnisse einer quantitativen Primärerhebung. Viedeň : WU Wien, Abteilung für Sozialpolitik.

BADELT, C. - BACHSTEIN, W. et al. 1997. Quantitative Dimensionen des Nonprofit Sektors in Österreich. Viedeň : WU Wien, Abteilung für Sozialpolitik.

BADELT, C. 2002. Der Nonprofit Sektor in Österreich. In Handbuch der Nonprofit Organisation. Strukturen und Management. Stuttgart : Schäffer Poeschel Verlag, 2002. ISBN 978-37-910-1941-3.

BENČO, J. - VACEKOVÁ, G. 2012. Theoretical-methodological problems of the scientific research. In Acta Moravia. Scientific journal for economics, management and informatics. Kunovice: European politechnic institute, Ltd. Vol. 3, No. 5, 2011, p. 3140. ISSN 1803-7607.

BRINCKERHOFF, P., C. 2011. Empowerment: More money for more mission (an essential guide for not-for-profit organizations). In Voluntas: International Journal of Nonprofit and Voluntary Sector Marketing. Vol. 1, Issue 4, 2011. p. 373-374. ISSN 1479-103X. 
BÚTORA, M. a kol. 2011. Štúdia súčasného stavu občianskej spoločnosti na Slovensku. [online] 2011. [cit. 2012-05-13]. Dostupné na internete: http://www.cpf.sk/files/File/Studia\%20sucasneho\%20stavu\%20OS\%20na $\% 20$ Slovensku.pdf

FRIČ, P., GOULLI, 2001. Neziskový sektor v České republice. Praha: Eurolex, 2001, s. 203. ISBN 80-86432-04-1.

HAIDER et al. 2010. Neue Datengrundlagen für den Nonprofit Bereich. In Statistische Nachrichten 63(8). Viedeň : Statistik Austria, 2010. p. 754-761.

HAKEN, R. 2005. Třetí sektor. In: Definice neziskového sektoru. Brno: Centrum pro výzkum neziskového sektoru, 2005, s. 10 - 12. ISBN 80-239-4057-0.

HANSMANN, H. 1996. The Changing Roles of Public, Private, and Nonprofit Enterprise in Education, Health Care, and Other Human Services. University of Chicago Press: 1996. ISBN 0-226-26786-5.

HEITZMANN, K. - Simsa, R. 2004. From Corporatist Security to Civil Society Creativity: The Nonprofit Sector in Austria, in: Zimmer, Annette; Priller, Eckhard (ed.), Future of Civil Society. Making Central European Nonprofit Organisations Work. Wiesbaden, VS Verlag für Sozialwissenschaften: 713-731.

HEITZMANN, K. 2001. Dimensionen, Strukturen und Bedeutung des Nonprofit Sektors - Eine theoretisch-konzeptionelle und empirische Analyse für Österreich. Viedeň, 2011.

HOCHEL, D. 1996. Public Policy in Slovakia: The Role and Status of the NGO Sector. [online] 1996. [cit. 2012-05-09]. Dostupné na internete: http://www.newschool.edu/centers/ecep/dino.htm

HYÁNEK, V. 2012. Neexistující sektor? Scientia et Societas, Praha: NC Publishing, 2012, Vol. 4, pp. 4-22. ISSN 1801-7118.

KLAS, A. 2010. Výskum ako faktor inovačného rozvoja. In: Ekonomický časopis / Journal of Economics. Vol. 58, Issue 9, 2010. p. 871-887. ISSN 0013-3035.

KO, Y. J. - GIBSON, H. - KIM, M. 2011. Understanding donors. In Voluntas: International Journal of Nonprofit and Voluntary Sector Marketing. Vol. 16, Issue 2, 2011. p. 166-182. ISSN 1479-103X.

KUVÍKOVÁ in Zimmer, 2004 ZIMMER, A. PRILLER, E. 2004. Future of civil society. Making Central European Nonprofit-Organizations work. 1. vydanie. Wiesbaden: VS Verlag, 2004. 736 p. ISBN 3-8100-4088-6.

KUVÍKOVÁ, H. - RAGUSEO, D. 2008 The Economic Rationale of Non-profit Organizations in the Delivery of Welfare Services. In Ekonomický časopis / Journal of Economics. Vol. 56, Issue 8, 2008. p. 764-780. ISSN 0013-3035.

KUVÍKOVÁ, H. - SVIDROŇOVÁ, M. 2010. Kvantitatívny rast a akceptácia súkromných neziskových organizácií v Slovenskej republike. In Bílá místa teorie a černé díry reforem ve veřejném sektoru II, Sborník příspěvků z mezinárodního 
vědeckého semináře 2010. Šlapanice : Ekonomicko-správní fakulta MU, 2010, p. 34. ISBN 978-80-7399-907-0.

KUVÍKOVÁ, H. 2004. Neziskové organizácie v Európskej únii. Ekonomická fakulta UMB, 2004. 88s. ISBN 80-8055-937-6.

LITTICH, E. 2007. Finanzierung in NGOs. In Handbuch der Nonprofit Organisationen. Stuttgart : Schäffer Poeschel Verlag, 2002. ISBN 978-37-910-1941-3.

MARKOWSKA-BZDUCHA, E. 2010. Struktury samorządowe w krajach Unii Europejskiej - organizacja i kierunki reform, [w:] Gospodarka finansowa jednostki samorządu terytorialnego. Zagadnienia wybrane, red. L. Patrzałek, Wydawnictwo Wyższej Szkoły Bankowej w Poznaniu, Poznań 2010, s. 153-159 ISBN 978-83-7205291-9.

MARČEK, E. 2004. Financovanie neziskového sektora na Slovensku po roku 1989. PANET. [online] 2004. [cit. 2010-02-05]. Dostupné na internete: http://www.partnerstva.sk/buxus/generate_page.php?

page_id=558.

MARČEK, E. 2010. Financovanie mimovládnych neziskových organizácií z verejných zdrojov na úrovni miestnych samospráv v SR. PANET. ISBN 978-80-968920-1-3.

NEMEC, J. - MERIČKOVÁ, B. - ŠTRANGFELDOVÁ, J. 2010. The ownership form of hospitals from the point of view of economic theory and the Slovak practice In: Ekonomie a manažment. Liberec : Technická univerzita v Liberci, ročník XIII, č. 2 s. 19 - 31, ISNN1212-3609

Obchodný vestník https://portal.justice.sk/PortalApp/ObchodnyVestnik/Web/Zoznam.aspx

ONDRUŠEK a kol. 1998. Č́́tanka pre neziskové organizácie. Centrum prevencie a riešenia konfliktov, Partners for Democratic Change - Slovakia, 1998. ISBN 80967890-5-8.

NEMEC, J. -ORVISKÁ, M. -PISÁR, P. 2010. European Structural Funds in Slovakia: Characteristics and Selected Realization Problems 2004-2006. In: Transfer wiedzy i funduszy europejskich do sektorov gospodarki krajow Unii Europejskej, s. 223-230. Poznan: Wydawnictwo Wyzszej szkoly bankowej, 2010. ISBN 978-83-7205-286-5

PESTOFF, V. 2006. Co-Production, the Third Sector and the Delivery of Public Services: An Introduction. In Public Management Review, roč. 8, č. 4, s. 493 - 519. ISSN 1471-9045.

RADVANSKÝ, M. - PÁLENÍK, V. - SLOBODNÍKOVÁ, S. 2010. Midterm Forecast of Slovak Economy for the Period 2010 - 2013 with Outlook to 2015. In Ekonomický časopis / Journal of Economics. Vol. 58, Issue 6, 2010. p. 614 - 634. ISSN 0013-3035.

REHLI, F. - JÄGER, U. P. 2011. The Governance of International Nongovernmental Organizations: How Funding and Volunteer Involvement Affect Board Nomination Modes and Stakeholder Representation in International Nongovernmental Organizations. In Voluntas: International Journal of Voluntary and Nonprofit Organizations. Vol. 22, No. 4, 2011. p. 587-612. ISSN 1573-7888. 
REKTOŘÍK, J. 2001. Organizace neziskového sektoru. Základy ekonomiky, teorie a řízení. Praha : EKOPRESS s.r.o., 2001. ISBN 80-86119-41-6.

ROSE-ACKERMAN, S. 1996. Altruism, Nonprofits, and Economic Theory. In: Journal of Economic Literature, č. 34, 1996, s. 701-728.

SALAMON, L. M., ANHEIER, H. K. 1998. Social origins of civil society: Explaining the nonprofit sector cross-nationally. In: Voluntas: International journal of voluntary and nonprofit organizations, Vol. 9, 1998, $\mathrm{N}^{\circ}$ 3, pp. 213-248. ISSN 0957-8765

SALAMON, L.M. - ANHEIER, H. 1992. In search of the non-profit sector. In Voluntas: International Journal of Voluntary and Nonprofit Organizations. Vol. 3, No. 2, pp. 125151. 2012. ISSN 1573-7888.

SCHNEIDER et al. 2007. Der Nonprofit Sektor in Österreich. In Handbuch der Nonprofit Organisationen. Strukturen und Management. Stuttgart : Schäffer Poeschel Verlag, 2002. ISBN 978-37-910-1941-3.

SCHNEIDER, U. - HAIDER, A. 2009. Nonprofit Organisationen in Österreich 2006. Forschungsbericht. Viedeň : Institut für Sozialpolitik, 2009.

SCHOBER et al. 2010. Die unterschiedlichen Finanzierungsquellen von NGOs. Ausgewählte deskriptive Ergebnisse zur NPO-Finanzierungsbefragung 2010. [online] 2010. [cit. 2012-08-30]. Dostupné na internete: http://www.wu.ac.at/npo/competence/research/abgeschlforsch

SIMSA, R. - SCHOBER, Ch. - SCHOBER, D. 2006. Das Wiener Vereinswesen im 20. Jahrhundert - Geschichte, Entwicklung und Hintergründe. Studienendbericht, Vienna.

SOKOLOWSKI, W. 2012. Effects of Government Support of Nonprofit Institutions on Aggregate Private Philanthropy: Evidence from 40 Countries. In Voluntas: International Journal of Voluntary and Nonprofit Organizations. Vol. , No., 2012. ISSN 1573-7888.

STEJSKAL, J. et al. Neziskové organizace - vybrané problémy ekonomiky. Wolters Kluwer ČR, a. s., Praha : 2012. ISBN 978-80-7357-973.

ŠPAČEK, D. - NESHYBOVÁ, J. 2010. Brief history and current trends of public administration reform in the Czech Republic. In Public Administration in Times of Crisis. Bratislava : NISPAcee, 2010. p. 1-18. ISBN 978-80-89013-52-4.

ŠPAČEK, D. 2009. Reformy veřejné správy - globální trendy. In Veřejná správa v kontextu prípravy a vstupu státu do euroźony. Brno : Masarykova univerzita, Ekonomicko-správní fakulta, 2009. p. 8-23. ISBN 978-80-210-4979-6.

Štatistický úrad SR - www.statistics.sk

Statistik Austria - www.statistik.at

SVIDROŇOVÁ, M. - VACEKOVÁ, G. 2012. Current state of self-financing of private non-profit organizations in the conditions of the Slovak Republic. In TEDE Technological and Economic Development of Economy. Taylor \& Francis. Vol. 18, No. 3, 2012. ISSN 2029-4913. 
SVIDROŇOVÁ, M. - VACEKOVÁ, G. 2013. Self -financing of Non -government Organizations versus General Benefit of their Goals. In Lenka Furová, Dagmar Špalková. Proceedings of the 17th International Conference. Current Trends in Public Sector Research. Brno: Masarykova Univerzita, 2013. s. 125 - 136, 320 s. ISBN 978-80 -210-6159-0.

TOEPLER, S., SALAMON L.M. 2003. NGO Development in Central and Eastern Europe: An Empirical Overview. East European Quarterly, Vol. 37, 2003.

WEISBROD, B. 1998. The Nonprofit Economy. Boston : Harvard University Press, 1998. ISBN 0-674626-25-7. 